\title{
Research on the Architectural Design Industry Human Resources Management System based on Competency Model
}

\author{
Zhang Juan ${ }^{1}$ \\ ${ }^{1}$ Xi'an International University, \\ Xi'an 710077,China
}

\begin{abstract}
In this paper, we conduct research on the architectural design industry human resources management system based on competency model. With the increasing competition in the market, the development and management of human resources has become an important means to improve the core competitiveness of construction enterprise. Competency directly affects the performance of individual condition and behavior characteristics, refers to a work achievements and personal characteristics of deep apart from the ordinary one. Our methodology will largely enhance the current management pattern which will be benefit for the modern enterprise.
\end{abstract}

Keywords: Human Resources Management; Competency Model; Architectural Design Industry.

\section{Introduction}

Human resource is the most important resource in enterprise. The development of the enterprise needs to have good human resources system to guarantee, therefore to build the enterprise human resources management system to locate in the management for the enterprise to solve the problem, the enterprise sustainable development. There are many successful enterprises, there are successful human resources management systems, but not copy can also achieve success, the key is to the actual situation of enterprises tailored for the enterprise human resources management system, namely, to establish the human resource management system of enterprise features.
Establish human resources management system must have integrity and systemic. Consider the enterprise's market environment and the life cycle. Not only must have the system must have the security system implementation measures. The construction enterprise human resources characteristic could be separated into the following parts. (1) Brain drain is serious. Construction because of the bad living conditions, working environment, salary is not high and the low social status to highquality talent away, even the existing talent also gradually lost. Under the market economy system, due to the openings of the current domestic construction market, and management is not standard, construction companies in almost find rice pot, hungry and passive situation, and therefore have relatively low social status. Combined with rewards and punishment dynamics is insufficient, not with the responsibility of the individual interests and risk effectively, without an effective incentive and restraint mechanism. (2) The great mobility and the structure are unstable. The construction industry itself is a based on the engineering, project contracting of special industries. Many work in the construction site for construction industry field. The project is over and the worker is withdrawn from the spot. As soon as new project start, they face new move. This is itself has the characteristics of construction industry, it leads to the industry's human resource fluidity big and the structure is relatively stable. (3) Unreasonable talent structure, the overall quality is low. Most of the workers in the construction enterprises in our country for a long time engaged in manual labor which is given priority to, extensive production 
labor rate are relatively low. These construction companies in the recruitment, because of the limitation of their own industry often higher requirements for the worker's physical condition, but for the worker's cultural quality request are not high. To introduce and develop simultaneously, give priority to in order to develop strategy. The key introduction of training high-level management and professional and technical personnel, scientific and technological innovation talents, advanced skills and transformation in the new field of much-needed professionals. Meet the needs of company development strategy planning of talent. Management diagnosis is to find enterprise management problems from the management problems in human resources management.

The elaborating management of human resources is the human resources management process, scientific elaboration and reasonable optimization process. The human resources of fine management goal is to obtain the biggest use value of employees, make employees the most effective skills, greatly reduce human resource cost. At the same time, by building a fine system of human resource management, for enterprises to attract and retain talent and provide a fundamental guarantee of sustainable development. A position to do analysis and demand planning and job vacancies in the enterprise, the first thing to do is not to find a person to fill this position, but rather through job analysis to determine what quality and ability of talents have qualified for the job, and then step by step, according to certain procedures to determine the candidate. At the same time, to talent for the enterprise and formulate feasible career planning [1-2].

To enhance the management system, in this paper, we research on the architectural design industry human resources management system based on competency model. Competency directly affects the performance of individual condition and behavior characteristics, refers to a work achievements and personal characteristics of deep apart from the ordinary one. It can be seen from its concept, closely related to competency and job performance. The theory of human resource management for the enterprise provides a new angle of view and competence has become a discussion focus of human resource performance management. In the following sections, we will discuss in detail.

\section{Our Proposed Methodology}

The Competency Model. Competency model is to point to undertake a particular job role required competency elements combined, are well according to the specific job requirements combined competency structure. Competency model offers a new way for the modern human resources management and development direction. Build based on competency model of human resource management system, can improve the rationality and validity of the exploitation and utilization of human resources which will improve enterprise's ability to cope with changeable environment risk. Build based on the competency model of human resource management system is the inevitable trend of modern human resources management, will help organizations achieve strategic objectives, implement people post match, realize win-win situation of organization and employees. Application of competency model in human resources management module is mainly embodied in the following. (1) Competency model in the application of performance management. Application of competency model in the performance management, can simplify the process of performance evaluation, make employees get more fair and accurate evaluation, encourage employees to improve their level of competency. When using the competency model, but also should pay attention to in the design of performance criteria considering competency development goal and task performance goals, balanced long-term performance and short-term performance. (2) Competency model in the application of the compensation management. Compensation management based on 
competency model by combining compensation, promotion and so on a variety of incentives, guide employees choose suitable for their career path and personal ability and career development was achieved by own ability quality promotion. Application of competency model in the compensation management, can help the state-owned enterprise more effectively absorb and retain more high-quality talents, encourage employees to constantly improve their ability of literacy, the efforts to play their own potential, to really play a role of incentive compensation management, improve employee job performance. (3) Competency model in the application of the training and development. Training and development is one of the most core functions of the competency model. Application of competency model in the training and development, focusing on according to post competency needed to train employees on development, staff training and development potential. (4) The application of the competency model in selecting talents. Application of competency model in selecting talents, it can examine all kinds of talents knowledge, skills, such as capacity at the same time, excavate the potential ability of all kinds of talents to find consistent with post needs more talents [3]. At the same time, the application of competency model, managers can more effectively manage and develop subordinate resources which carry out based on the competency of human resource management.

Competency model is a new economic era of human resource management provides a new train of thought, should be widely in each aspect. The management of human resource management is a dynamic process, every link have different business content and method, and competency model is to provide a common reference standards, clear description of the competency of up to a certain job or position. The state-owned construction enterprise is the product of planned economy. With the continuous development and improvement of market economy, state-owned construction enterprises are due to problems such as its own mechanism greatly hindered the pace of progress. Therefore, combining the mode with architectural design industry human resources management is necessary.

The Architectural Design Industry Human Resources Management. Construction enterprises of production and operation, in the form of project and project usually is one-off, decided the construction enterprise has the characteristics of different from general manufacturing enterprises, also determines the construction enterprise mainly revolves around the project management to human resources management. As the main body of the stateowned construction enterprise market economy, its survival and development is facing a growing external pressure of competition of the market. Evolution, survival of the fittest has become a state-owned construction enterprises must face the grim reality. At the same time, under the condition of market economy, market competition has become an important means to promote the optimal allocation of resources. The market competition of modern society, the first is the competition of productivity, behind the competition, and productivity is the talent competition. This suggests that economic competition has turned to the competition of human resources. State-owned construction enterprises must, therefore, the implementation of modern human resources management innovation, in order to better play a role of important factor of the dynamic human resources, and fundamentally improve the competitive ability of enterprises, make the enterprise gain a foothold in the fierce market competition which is to obtain sustainable growth and development. Construction industry is a major industry, manual work is characterized by a strong liquidity, the intensity of labor is big, tough industry, is also a very inefficient industries. Displays in the scale of production are large but low efficiency.

With the increasing competition in the market, the development and management of 
human resources has become an important means to improve the core competitiveness of construction enterprise. Construction enterprise if we want to survive in the fierce market competition and development and must realize the importance of human resource management, clear the concept of human resources management. First of all, the construction enterprise need to recognize that only systematic and professional management, to provide strong guarantee for the development of enterprises, human resources management must also be due to the enterprise internal and external environment changes and adjustments in a timely manner, make its moment in the dynamic management. For example, the construction enterprise human resource management department needs on the basis of the enterprise development milestones, for the purpose of introducing and cultivating professional talents of the corresponding enterprise in order to ensure the smooth realization of the enterprise development milestones [4].

Construction enterprises need to provide human resources management platform. Construction enterprise human resource management department only to enterprise's development direction, existing problems and facing opportunity and challenge to have a clear understanding, to the development of human resources management and proactive direction forecast, can jump out from the daily chore of personnel management work, to the enterprise human resources management to design a longterm planning, in order to provide sufficient personnel for the development.

The Competency Model based Management Methodology. In empirical research, at present our country based on the competency model of human resource management research literature are not enough, most of the researchers focused on building position competency model and to explore the competency model and the relationship among the variables such as enterprise performance, rather than how to build based on the competency model of human resource management system, etc. As stated earlier, competency model is built based on the competency model of human resource management system is the basis and premise. Studied the therefore, the competency model building and based on competency model can help the development of human resources management related theory. In the following figure, we illustrate the model visually with flowchart.

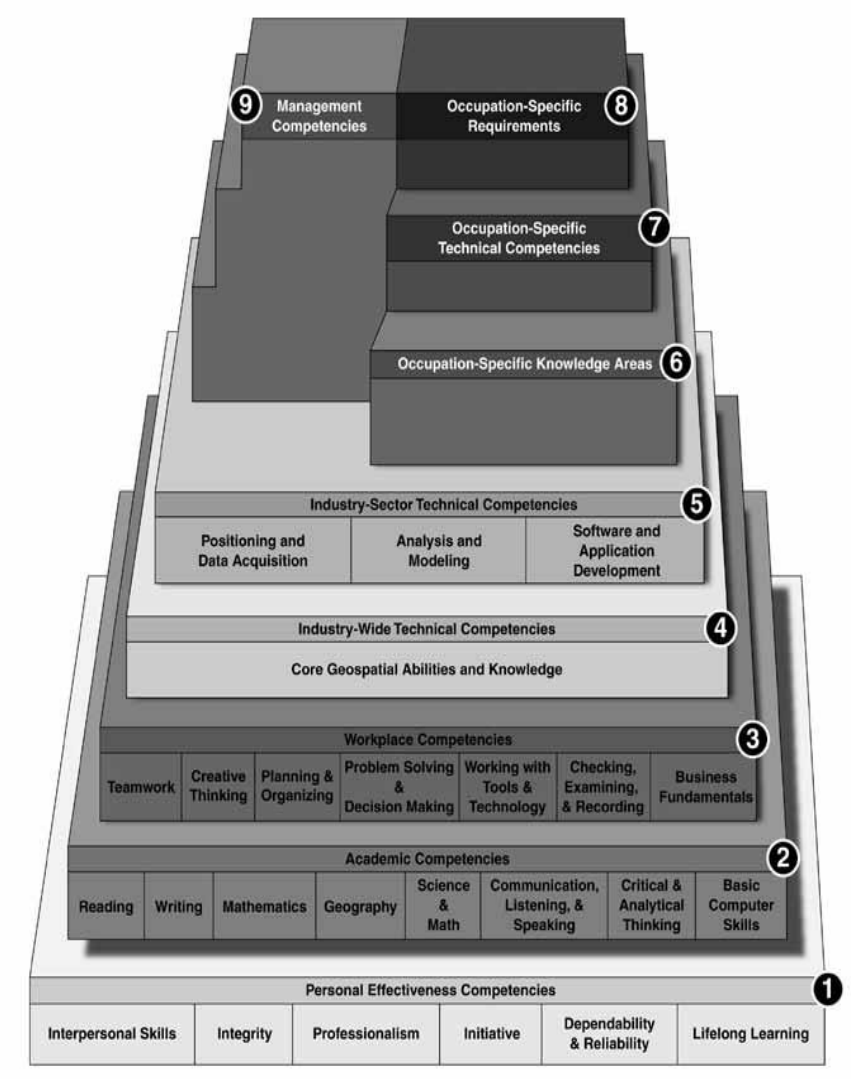

Figure 1. The Demonstration of the Proposed Methodology

\section{Conclusion}

In this paper, we research on the architectural design industry human resources management system based on competency model. Compared with the traditional post training, training system based on the competency model, the organization needs to take measures to ensure that staff training of competence is needed for 
the organization development competence, and to establish security staff training system of what they have learned to use in practice. Competency model was applied to the training and development, to be able to make the stateowned enterprise competency requirements in specific jobs, and the staff's ability quality characteristics to set up the training course, thereby enhancing the effect of training and development. In the future, we plan to combine more related theory to modify the traditional human resources management system.

\section{References}

[1] Bao R B, Zhang M. A Research on Construction of Information Management Platform for the Architectural Design
Industry Based on the Life Cycle Theory[J]. Applied Mechanics \& Materials.

[2] Ding W. The Development of Architectural Design Management System Based on Petri Nets[J]. Advances in Intelligent \& Soft Computing, 2012.

[3] Gao B. The Architectural Design on Establishing the Network Management System of Forestry Resources[J]. Forest Inventory \& Planning, 2002.

[4] Watashiba Y, Date S, Abe H, et al. An Architectural Design of a Job Management System Leveraging Software Defined Network[C]. 2013 IEEE 37th Annual. IEEE, 2013:724-729. 